\title{
CHRYSTOLOGICZNA INTERPRETACJA KSIĘGI OZEASZA W STAROŻYTNOŚCI I ŚREDNIOWIECZU
}

Księga Ozeasza komentowana była przeważnie w ramach całości korpusu ksiąg Proroków Mniejszych. Dlatego też w chrześcijaństwie greckojęzycznym najważniejszymi komentarzami są dzieła Teodora z Mopswestii, Cyryla Aleksandryjskiego, Teodoreta z Cyru i Hezychiusza z Jerozolimy, wśród łacińskich pisarzy epoki patrystycznej mamy Hieronima, Juliana z Eklanum i Bedę Czcigodnego, natomiast z pisarzy syryjskich komentarze do tej księgi napisali Efrem i Iszodad $\mathrm{z}$ Merw. ${ }^{1} \mathrm{~W}$ naszym artykule nie tylko powołujemy się na powyższe komentarze, ale sięgamy również do interpretacji Księgi Ozeasza rozsianych w innych tekstach starożytnych i średniowiecznych.

Odniesienia chrystologiczne, jakich tradycja chrześcijańska doszukuje się w Księdze Ozeasza, mają zasadniczo dwojaki charakter. Na poziomie sensu historycznego są to motywy literackie księgi, które w sensie dosłownym odczytywane były jako zapowiedzi prorockie dotyczące Jezusa. Natomiast na poziomie sensu ponaddosłownego niektóre motywy literackie Księgi Ozeasza odczytywano jako symbole wskazujące na Jezusa.

\section{Metafora oblubieńcza}

Zacznijmy od motywu o szczególnym charakterze, mającego wymiar zarówno historyczny, jak i odniesienie symboliczne - oblubieńczej miłości Boga do swojego ludu. Metafora miłości oblubieńczej Boga do Izraela jest głęboko zakorzeniona w tradycji hebrajskiej.

1 Omówienie komentarzy i odnośniki bibliograficzne do wydań, zob. K. B a r d s k i, Ksiega Amosa w interpretacji patrystycznej, Collectanea Theologica 85(2015)4, s. $197-200$. 
Wystarczy przypomnieć chociażby alegorię Jerozolimy z Księgi Ezechiela (16,1-63) oraz tradycyjny klucz hermeneutyczny interpretacji Pieśni nad Pieśniami.

W Nowym Testamencie Jan Chrzciciel ukazuje Jezusa jako Oblubieńca: „Ten, kto ma oblubienicę, jest Oblubieńcem; a przyjaciel Oblubieńca, który stoi i słucha Go, doznaje najwyższej radości na głos Oblubieńca (...) Trzeba, aby On wzrastał, a ja żebym się umniejszał" (J 3,29-30). Również sam Jezus odnosi do siebie metaforę oblubieńczą, wskazując pośrednio na swoją Boską naturę: „Czy goście weselni mają pościć dopóki Oblubieniec jest z nimi” (Mt 9,15 i par.). List do Efezjan w sposób najbardziej wyrazisty ukazuje Jezusa jako oblubieńca Kościoła: „Mężowie, miłujcie żony, bo i Chrystus umiłował Kościół i wydał za niego samego siebie (...) Tajemnica to wielka, a ja mówię: w odniesieniu do Chrystusa i Kościoła" (Ef 5,25.32).

Postać Ozeasza, który z polecenia Boga ma poślubić kobietę nierządną (Oz 1,2-9), według Orygenesa symbolizuje Jezusa, który przyjmuje do Kościoła pogan, a więc tych, którzy „uprawiali nierząd” z obcymi bogami. ${ }^{2}$ We wstępie do Komentarza do Księgi Ozeasza Hieronim wyjaśnia, że cokolwiek czynią prorocy, odnosi się do podobieństwa do Chrystusa (,Quidquid prophetae jubentur operari, ad meam refertur similitudinem"). Dotyczy to także poślubienia nierządnicy przez Ozeasza, co zapowiada i symbolizuje Chrystusa i Kościół złożony z ludzi grzesznych. ${ }^{3}$

Podobnie Grzegorz z Nyssy, w prologu do Komentarza do Pieśni nad Pieśniami wymienia Ozeaszowy epizod małżeństwa z nierządnicą jako jeden z wielu biblijnych związków oblubieńczych,

2 Orygenes, Commentarii in Matthaeum, 12,4, ad Mt 16,1-4; 14,20, ad Mt 19,3-11; GCS 40, opr. E. K 1 o s t e r m a n n, E. B e n z, Leipzig 1935, s. 75, 333; t o ż, ŹMT 10, tłum. K. A u g u s t y n i a k, Kraków 1998, s. 113, 223; O r y g e n e s, Homiliae in Iosue, 3,4; GCS 30, opr. W.A. B a e h r e n s, Leipzig 1921, s. 305; t o ż, PSP 34/2, tłum. S. K a 1 i n k o w s k i, Warszawa 1986, s. 19.

3 „Nec mirum si in figura Domini Salvatoris, et Ecclesiae de peccatoribus congregatae, haec facta memoremus"; $\mathrm{H}$ i e r o $\mathrm{n}$ i m, Commentaria in Osee, prol; PL 25,818B. 
których interpretacja nie powinna ,zatrzymać się tylko na dosłownym znaczeniu". 4

Fundamentalnym tekstem jest w tym względzie obietnica Boża z Oz 2,21-22: „Poślubię cię sobie na wieki, poślubię przez sprawiedliwość i prawo, przez miłość i miłosierdzie. Poślubię cię sobie przez wierność i poznasz Pana". Orygenes przytacza ten werset w kontekście duchowej interpretacji Rdz 24,15-16 (Rebeka przybywa do studni, by zaczerpnąć wody, i spotyka sługę Abrahama): „Chrystus pragnie i ciebie zaręczyć ze sobą, do ciebie się bowiem zwraca, gdy mówi przez proroka: Zaślubię cię ze sobą na wieki, poślubię cię w wierze i miłosierdziu, a poznasz Pana". ${ }^{5}$ Ponieważ więc pragnie zaręczyć cię ze sobą, posyła do ciebie przodem owego sługę. Sługą tym jest mowa prorocka: „Jeśli jej wprzód nie przyjmiesz, nie będziesz mógł poślubić Chrystusa". ${ }^{6}$ Komentarz Orygenesa wpisuje się w drugi nurt alegorycznej interpretacji miłości oblubieńczej Chrystusa: nie tylko miłość do Kościoła, ale do każdego chrześcijanina indywidualnie. Równocześnie w innym miejscu poświadcza tradycyjną interpretację Chrystus-Kościół: „Chrystus przybrał sobie Kościół w prostej wierze. (...) Ona [Kościół] wytrwała w prostym wyznaniu jakby w dziewiczej czystości. Tak bowiem już dawno obiecał, przemawiając przez proroka: Poślubię cię przez wiarę".

Chromacjusz z Akwilei (†408), przedstawiając małżeński związek Jezusa z Kościołem, przywołuje na zasadzie skojarzenia reminiscencyjnego współbrzmiące wersety: Ps 19,6 („Jak oblubieniec wychodzi

4 Grzegorz z Nys s y, Homiliae in Canticum Canticorum, prol.; GNO 6, opr. H. L a n g e r b e c k, Leiden 1986, 7; t o ż, tłum. M. P r z y s z y c h ow s k a, ŹMT 43, Kraków 2007, s. 19.

5 Orygenes skraca werset. W Septuagincie hebr. be'ěmûnâ (,przez wierność”)

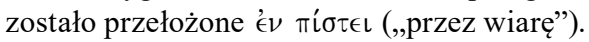

6 O r y g e n e s, Homiliae in Genesim, 10,2; GCS 29, opr. W.A. B a e h r e n s, Leipzig 1920, s. 95; t o ż, PSP 31/1, tłum. S. K a l i n k ow s k i, Warszawa 1984, s. 108.

7 Te n ż e, Homiliae in Leviticum, 12,5; GCS 20, opr. W.A. B a e h r e n s, Leipzig 1920, s. 463; t o ż, PSP 31/2, tłum. S. K a 1 i n k ow s k i, Warszawa 1984, s. 164. 
ze swej komnaty”); Iz 62,5 (,,Jak młodzieniec poślubia dziewicę, tak twój Budowniczy ciebie poślubi, i jak Oblubieniec weseli się z oblubienicy, tak Bóg twój tobą się rozraduje”) i Pnp 5,1 (,Wchodzę do mego ogrodu, siostro ma, oblubienico"). ${ }^{8}$

Metafora oblubieńcza wyraża nie tylko miłość Chrystusa do Kościoła lub indywidualnego człowieka, lecz również potrzebę odpowiedzi. Ze strony niewiernej małżonki, ważne w świetle misterium Chrystusa są słowa Oz 2,9b: „I powie: Pójdę i wrócę do mego męża pierwszego, bo wówczas lepiej mi było niż teraz".

Orygenes $^{9}$ odnosi ten werset do duszy człowieka, który oddalił się od jedynego Boga, by czcić fałszywe bóstwa (metaforycznie uprawiać z nimi nierząd). Po powrocie Bóg - prawdziwy małżonek duszy - otacza ją miłosierdziem i nie pamięta grzechów. Również Grzegorz Wielki ${ }^{10}$ widzi tu słowa grzesznika powracającego do Boga.

Nietrudno też dostrzec analogię do sytuacji przedstawionej w przypowieści o synu marnotrawnym (Łk 15,11-32), zwłaszcza dotyczy to decyzji powrotu oraz konstatacji, że stan, w jakim znalazła się niewierna małżonka, jest gorszy od tego, jakim się cieszyła, będąc ze swoim małżonkiem.

\section{Odniesienia chrystologiczne na poziomie sensu historycznego}

Najważniejszy z perspektywy nowotestamentowej tekst Ozeasza, który został powtórzony niemalże literalnie w Mt 9 13, to Oz 6,6: „Miłosierdzia chcę, a nie krwawej ofiary, poznania Boga bardziej niż całopaleń".

8 Chromacjusz z A kwilei, Commentarium in Matthaeum, 46,2, ad Mt 9,14,17; CCL 9A, opr. R. Ét a i x, J. L e m a r i e, Turnhout 1974, s. 422.

9 O r y ge ne s, Homiliae in Exodum, 8,4; GCS 29, opr. W.A. B a e h r e n s, Leipzig 1920, s. 224-226; PSP 31/1, tłum. S. K a 1 i n k o w s k i, Warszawa 1986, s. 227.

10 Grzegorz Wi el k i, Homilia 34, 9; SCh 522, opr. R. Ét a i x, G. B 1 a n c, Paris 2008, s. 410; PSP 3, tłum. W. S z ołd r s k i, Warszawa 1970, s. 275-276. 
Wśród pisarzy pierwszych dwóch wieków najczęściej cytuje werset Tertulian - aż 9 razy, z czego 7 w Adversus Martionem, ${ }^{11} \mathrm{w}$ celu podkreślenia dobroci i miłosierdzia Boga objawiającego się w Starym Testamencie. Werset ten odgrywał ważną rolę w kontekście polemiki z dualizmem bóstwa głoszonym przez Marcjona. Ten sam Bóg miłosierny i litościwy jest Panem Starego Testamentu i Ojcem Jezusa w Nowym Testamencie. Pośród pisarzy III w., poza Orygenesem, werset cztery razy cytuje Ps-Klemens Rzymski, z czego trzy w Recognitiones. ${ }^{12}$

W tradycji chrześcijańskiego Wschodu jest to werset Ozeasza najczęściej cytowany przez Jana Chryzostoma. Przeważnie pośrednio, gdyż przede wszystkim autor cytuje Ewangelię, jednak ma świadomość, że Jezus podejmuje tu wcześniejsze nauczanie prorockie: „Wyraża to, co głosili wszyscy prorocy, mówiąc: Miłosierdzia chcę, a nie ofiary". ${ }^{13}$ Konkluduje: ,[Jezus] przytacza świadectwo Starego Testamentu, który głosi i przykazuje zgodnie z Nim". ${ }^{14}$ Są to zatem słowa Ewangelii literalnie zawarte w tekście Starego Testamentu. Chrystus, który mówi ustami Ozeasza.

Podobnie Hieronim widzi w słowach Jezusa świadectwo proroka („de propheta proferens testimonium”). ${ }^{15}$ Ambroży zaś cytuje werset dwukrotnie w kontekście polemicznym. Raz przeciw nowacjanom w De paenitentia, ${ }^{16}$ następnie zaś w liście, upominając

11 Te r t u 1 i a n, Adversus Martionem, CCL 1, opr A. K r o y m a n n, Turnhout 1954, s. 441-626.

12 K le me n s R z y m s k i, Recognitiones; GCS 51, opr. B. R e h m, Leipzig 1965.

13 Jan Chryzos to m, Homilia 30, 3; PG 57,365; to ż, ŹMT 18, tłum. J. K r y s t y n i a c k i, Kraków 2003, s. 357.

14 Tamże.

15 H i e r o n i m, Commentarius in Matthaeum, 1, ad Mt 9,13; SCh 242, opr. E. B o n n a rd, Paris 1977, s. 172; t o ż, ŹMT 46, tłum. J. K or c z a k, Kraków 2008, s. 48.

16 A m b r o ż y, De paenitentia, 1,3,11; CSEL 73, opr. O. F a 11 e r, Wien 1955 , s. 124; t o ż, PSP 7, tłum. W. S z o łd r s k i, Warszawa 1971, s. 23. 
cesarza Teodozjusza, ${ }^{17}$ trudno jednak rozstrzygnąć, czy odwołuje się do Ozeasza, czy raczej do Mt 9,13.

Wymiar profetyczny dostrzegano w numerycznej aluzji do trzeciego dnia, w którym Chrystus zmartwychwstał oraz do obietnicy powszechnego zmartwychwstania: „Po dwóch dniach przywróci nam życie, a dnia trzeciego nas dźwignie i żyć będziemy w Jego obecności” (Oz 6,2). W zamyśle autora chodzi o literacki zabieg numeryczny, podobnie jak w Prz 30, 15.18.21.29, jednak literalne odczytanie sugeruje skojarzenie ze zmartwychwstaniem Jezusa trzeciego dnia po ukrzyżowaniu.

Orygenes w ten sposób wyjaśnia werset: „Pierwszym dniem jest dla nas męka Zbawiciela, drugim - dzień, w którym Zbawiciel zstąpił do Otchłani, trzecim zaś dzień zmartwychwstania". ${ }^{18}$ Taką samą interpretację znajdujemy w Clavisie Pseudo-Melitona z Sardes, ${ }^{19}$ który postrzega $\mathrm{w}$ tym wersecie nawiązanie do tajemnicy męki, śmierci i zmartwychwstania Jezusa.

Kolejnym wersetem, któremu tradycja chrześcijańska przypisywała znaczenie profetyczne, jest Oz 11,1: „Miłowałem Izraela, gdy jeszcze był dzieckiem, i syna swego wezwałem z Egiptu”. W ujęciu historycznym metafora syna odnosi się do starożytnego Izraela. Werset ma budowę chiastycznego paralelizmu:

„miłowałem Izraela” = ,wezwałem z Egiptu”

„gdy jeszcze był dzieckiem” = ,i syna swego"

„Dziecko" i ,syn” odpowiadają sobie wzajemnie, natomiast miłość do Izraela jest paralelnie skorelowana z wyjściem z Egiptu, które chronologicznie miało miejsce u początków istnienia narodu wybranego (,gdy jeszcze był dzieckiem”).

Ewangelista Mateusz literalnie interpretuje sformułowanie ,Syna swego” i odnosi werset do powrotu Świętej Rodziny z Egiptu: „Aby

17 Te n ż e, Epistulae, 11 (51), 15; CSEL 82/3, opr. M. Z e 1 z e r, Wien 1982, s. 218.

18 O ryge ne s, Homiliae in Exodum, 5,2, s. 186 (193).

19 Pse udo-Meliton z Sardes, Clavis, 5,12; wyd. J.-P. L a u rant, Symbolisme et Écriture, Paris 1988, s. 273. 
się wypełniło, co zostało powiedziane przez Pana za pośrednictwem proroka: Z Egiptu wezwałem Syna mego" (Mt 2,15).

Hieronim przytacza związek Mateuszowego tekstu z Ozeaszem na potwierdzenie prawdy ksiąg hebrajskich (,veritas hebraeorum voluminum"). ${ }^{20}$ Również Orygenes, komentując podobne sformułowanie w Księdze Liczb: „Bóg wyprowadził Go z Egiptu” (Lb 24,8), cytuje tekst Ozeasza, interpretując go chrystologicznie. Nie neguje znaczenia historycznego, ale dodaje również interpretację symboliczną: ,Zdanie to można rozumieć również w sensie alegorycznym: skoro przyszedł do Egiptu tego świata, Ojciec «wyprowadził Go» i przyjął do siebie, aby On otworzył drogę tym, którzy z Egiptu tego świata mają się wznieść do Boga". ${ }^{21}$ Ozeaszowy powrót Syna z Egiptu ma zatem w ujęciu Orygenesa dwustopniowe odniesienie. Najpierw zapowiadał przybycie Świętej Rodziny znad Nilu, następnie zaś powrót każdego wierzącego do niebiańskiej ojczyzny.

Euzebiusz z Cezarei w Demonstratio Evangelica dowodzi wypełnienia się tego proroctwa w Jezusie, ${ }^{22}$ natomiast w Eklogach, zapewne pod wpływem tradycji Orygenesowej, dodaje interpretację alegoryczną wersetu: Egiptem jest zdolność jedynie rozumowego pojmowania i rzeczywistość doczesna, z której Jezus wyprowadza nas ku niebu. ${ }^{23}$

Aluzji do wcielenia Jezusa doszukiwano się, opierając się na odmiennym tłumaczenie Oz 9,12b w Septuagincie. Hebrajski tekst brzmi: „Biada im samym, kiedy się od nich oddalę” (literalnie, z użyciem formy infinitivus constructus: ,,W moim oddaleniu się od nich”).

Słowo $b^{e}$ sûrî (,w moim oddaleniu”), opierając się na tekście niewokalizowanym, zostało przez tłumaczy LXX odczytane jako $b{ }^{e}$ sarî

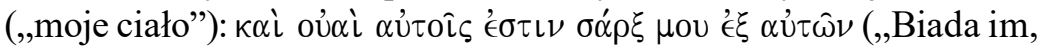

20 H i e r o $\mathrm{n}$ i m, Commentarius in Matthaeum, 1, ad Mt 2,15, s. 84 (16).

${ }^{21}$ O r y g e n e s, Homiliae in Numeros, 17,6; GCS 30, opr. W.A. B a e h r e n s, Leipzig 1921; t o ż, PSP 34/1, tłum. S. K a 1 i n k o w s k i, Warszawa 1986, s. 181.

22 E u z e bi us z z C e z a r e i, Demonstratio Evangelica, 9,4,11; GCS 23, opr. I.A. H e i k 1, Leipzig 1913, s. 411-413.

23 Te n ż e, Eclogae propheticae, 1,13; PG 22, 1069D. 
jest moje ciało z nich"), następnie zaś w przekładzie Vetus Latina: „Vae illis, quoniam caro mea ex ipsis est”. Dopiero w tłumaczeniu Hieronima został oddany sens oryginalnego tekstu hebrajskiego: „Sed et vae eis, cum recessero ab eis”.

Dlatego u autorów tradycji greckiej oraz tych, którzy nie korzystali z Wulgaty, lecz z przekładów starołacińskich, pojawia się odniesienie do wcielenia Chrystusa. Chromacjusz z Akwilei podkreśla fakt, że Syn Boży przyjął ciało w narodzie żydowskim, ${ }^{24}$ natomiast afrykański autor Wigiliusz z Tapsus (V w.) szerzej interpretuje zaimek ,ex ipsis", jako odnoszący się do całej ludzkości. ${ }^{25}$

\section{Odniesienia chrystologiczne na poziomie symboliki}

Oz 6,3 w literalnym przekładzie z hebrajskiego brzmi: ,Jak poranek [jest] pewne wyjście Jego, przyjdzie jak wczesny deszcz dla nas, jak deszcz późny, nasycający ziemię". Jednak pierwsze słowa wersetu inaczej zostały oczytane w Septuagincie. Hebrajskie môşā' $\hat{o}$ (,,jego wyjście"26 od czasownika jaşa $\bar{a}$-,,wychodzić”) tłumacz grecki odczytał ,,jego odnalezienie” (przez nas), od czasownika maşā '-

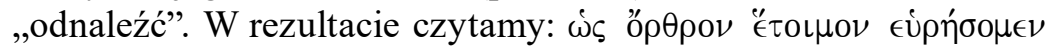

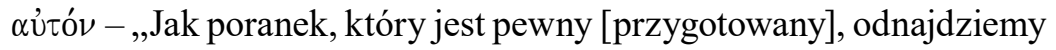
Go". 27

Porównanie przyjścia Chrystusa do poranka nawiązuje do symboliki solarnej: Jezus - w myśl słów Malachiasza - jest „Słońcem sprawiedliwości, w którego skrzydłach jest uzdrowienie" (M1 3,20), to w Nim „nawiedzi nas Słońce Wschodzące z wysoka” (Łk 2,78).

24 Por. Chromacjusz z A k wile i, Commentarium in Matthaeum, 50A, ad Mt 12,38-42; 51A,3.

25 ,Ita ergo ait agnum ex ovibus, et haedum de capris, et vitulum ex bobus, ac si diceret hominem de hominibus"; Wigilius z z Tapsus, Contra Eutychetem, 3,5; PL 62,114A-B.

${ }^{26}$ W domyśle: $z$ miejsca swego przebywania do nas, słuszne jest więc tłumaczenie ,,jego przyjście”, jak czytamy w Biblii Tysiąclecia.

27 Za Septuagintą Wulgata ma: ,Tamquam diluculum paratum inveniemus eum". 
Pisząc o nawróceniu, Augustyn przedstawia Chrystusa jako tego, który zawsze nas oczekuje: „W doskonałym naszym nawróceniu, spotykamy oczekującego na nas Boga, jak powiada prorok: «Jak poranek, który jest pewny, odnajdziemy Go». Ponieważ kiedy tracimy Go, to nie Jego obecność, albowiem jest wszędzie, lecz to my odwracamy się od Niego". ${ }^{28}$

Również symbol deszczu był odnoszony do Jezusa. Garnier z Langres interpretuje ,wczesny deszcz” jako przyjście Jezusa do pogan, by wylać na nich łaskę nawrócenia, natomiast „deszcz późny”, jako nawrócenie Izraela przy końcu czasów, ${ }^{29}$ wieszczone przez św. Pawła (por. Rz 11,25-27).

Również w Oz 13,15 zjawiska atmosferyczne zyskały w tradycji chrześcijańskiej symbolikę chrystologiczną: „Przyjdzie wiatr wschodni, od Pana wiatr powieje z pustyni, wysuszy źródła, i wyschną studnie; zrabuje jego ziemię i wszystkie rzeczy drogocenne".

Na poziomie historycznym tekst zapowiada klęskę, jaka dotknie Efraima, czyli Królestwo Północne Izraela po podziale państwa Salomona. Z perspektywy symbolicznej mamy znowu skojarzenie solarne (,wiatr wschodni”), który w tym kontekście jest przedstawiony jako „wiejący z pustyni”. Garnier z Langres odczytuje motyw „,pustyni” w odniesieniu do dziewictwa Maryi. „Pustynią” jest Jej łono, które nie zrodziło nikogo innego, jak tylko Jezusa (,wiatr wschodni”), syna Ojca Przedwiecznego („od Pana wiatr powieje”). ${ }^{30}$

Ostatni tekst, który chcielibyśmy omówić w ramach ponaddosłownej interpretacji chrystologicznej Księgi Ozeasza, zawiera poważne problemy translatoryczne. Tekst hebrajski Oz 10,12 w dosłownym

${ }^{28}$ A u g u s t y n, Enarrationes in Psalmos, 6,5; CCL 38, opr. D.E. D e k k e r s, I. F r a i p o n t, Turnhout 1956, s. 30; t o ż, PSP 37, tłum. J. S u l o w s k i, Warszawa 1986, s. 70. W polskim tłumaczeniu J. Sulowski zaczerpnął cytat z Biblii Tysiąclecia (czyli z przekładu z hebrajskiego), dlatego poprawiamy na wersję wierną tekstowi Augustyna, czyli pośrednio Septuagincie i Wulgacie.

${ }^{29}$ G a r n i e r z L a n g re s, Allegoriae totius Scripturae, imber; PL 112,970A-B.

30 ,Desertum, uteru virginis, ut in Osee: «Adducet Deus ventum urentem de deserto [32];» quod Deus Pater produxit nobi Christum potentem de utero virginis"; tamże, desertum; PL 112,908C. 
przekładzie brzmi: „wykarczujcie sobie karczowisko”, natomiast

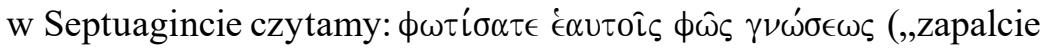
sobie światło wiedzy").

Różnice w greckim tłumaczeniu można wyjaśnić następująco:

1. Tłumacz Septuaginty odczytał czasownik nîrû jako wywodzący się z rdzenia $n w r$ (,zapalić”) a nie njr (,wykarczować”).

2. Rzeczownik nîr może przyjmować dwa znaczenia: „światło” lub „dziewicza, wykarczowana rola”, w zależności od kontekstu, więc w świetle wcześniejszej uwagi tłumaczenie Septuaginty jest całkiem logiczne.

3. Występujące w dalszej części wersetu słowo $w^{e}$ ‘et (,,i czas”) został odczytane w formie niewokalizowanej da'at (,wiedza”), ponieważ hebrajskie litery waw i dalet $\mathrm{w}$ niektórych rękopisach mogą wyglądać bliźniaczo podobnie i często bywały mylone.

Orygenes, opierając się na symbolice światła, a zwłaszcza na słowach Jezusa „Ja jestem światłością świata” (J 8,12), odnalazł w tym wersecie odniesienie chrystologiczne: „Jeśli zaś ponadto zgodnie ze słowami Ozeasza: ${ }^{31}$ "zapalicie sobie światło wiedzy», zdobędziesz sobie światło wiedzy i oświeci cię Słońce Sprawiedliwości", ${ }^{32}$ którym, jak wcześniej wspomnieliśmy, jest Jezus Chrystus.

Hieronim we Wulgacie tłumaczy zgodnie z oryginałem hebrajskim: „Innovate vobis novale”. W napisanym wcześniej Komentarzu do Ozeasza zwraca uwagę na różnicę, jaka zachodzi w Septuagincie. Proponuje poprawną wersję tłumaczenia, ale w komentarzu nie odrzuca tradycyjnego przekładu, obecnego również w wersji Vetus Latina. ${ }^{33}$ Wprawdzie nie stosuje w interpretacji klucza chrystologicznego, lecz rozumie werset jako zachętę skierowaną do heretyków, aby

31 W tłumaczeniu Rufina mamy w tym miejscu „Izajasza”, co jest oczywistą pomyłką.

32 O r y g e n e s, Homiliae in Iosue, 19,4, s.414 (106).

33 W takiej wersji cytuje Hieronim werset w listach; H i e r o $\mathrm{n}$ i m, Epistula 64 ad Fabiolam, 21; CSEL 45, opr. I. H i 1 b e r g, Wien 1996, s. 612 i w komentarzu do Księgi Koheleta, t e n ż e, Commentarius in Ecclesiasten, ad 2,24-26; CCL 72, opr. M. Adri e n, Turnhout 1959, s. 272; t o ż, BOK 5, tłum. K. B a r d s k i, Kraków 1995, s. 51. 
„W Starym Testamencie siali sprawiedliwość a w Nowym zbierali żniwo miłosierdzia, aby zapalili światło wiedzy lub wykarczowali karczowisko i szukali Pana, który może ich nauczyć prawdziwej sprawiedliwości". ${ }^{34}$

Ambroży, który odwoływał się do starołacińskiego tłumaczenia Biblii, raz nawiązuje do wersetu w De Isaac vel anima, lecz nie w znaczeniu chrystologicznym: „Światło poznania oznacza posiadanie doskonałości w miłości”. ${ }^{35}$

Reasumując, możemy stwierdzić, że Księga Ozeasza zawiera kilka istotnych tekstów, które w sensie profetycznym były interpretowane w odniesieniu do Jezusa Chrystusa, natomiast trzeba przyznać, że motywy symboliczne, które wzbogaciłyby interpretację chrystologiczną, są relatywnie nieliczne i nie tak relewantne dla tradycji chrześcijańskiej, jak w przypadku innych ksiąg biblijnych. Wyjątkową rolę pełni jedynie symbolika oblubieńczej miłości Boga do swojego ludu, która postać Ozeasza łączy w sposób typologiczny z osobą Chrystusa, Oblubieńca Kościoła.

ks. Krzysztof BARDSKI

Slowa kluczowe: hermenutyka biblijna, chrystologiczna interpretacja Starego Testamentu, Księga Ozeasza, symbolika

Keywords: Biblical Hermeneutics, the christological interpretation of the Old Testament, The Book of Hosea, symbolism

34 „In Veteri iustitiam seminent, in Novo metant misericordiam: et illuminent sibi lumen scientiae, sive innovent sibi novalia, et requirant Dominum, qui docere eos potest veram iustitiam"; H i e r o n i m, Commentaria in Osee, ad 10,12; PL 25,911B.

35 A m broż y, De Isaac, 4,23; CSEL 32/1, opr. C. S c h e n k 1, Wien 1897, s. 657; t o ż, PSP 35, tłum. P. L i b e r a, Warszawa 1986, s. 39. 


\section{The Christological Interpretation of Hosea in Antiquity and the Middle Ages \\ Summary}

The Christian interpretations of the prophet Hosea in the light of the mystery of Christ follow three ways. Firstly, the life of the prophet and his marriage to an adulterous woman (Hos 1:2-9) was seen as a typological prefiguration of the marriage of Christ and the Church (Hos 2:9,21-22). Secondly, some verses have been interpreted on the historical level as a prophetic annunciation of the coming of Christ, containing his teachings (Hos 6:6) or foretelling events of his life (Hos 6:2; 9:12; 11:10). Finally, on the symbolic level, some literary motifs have been connected in a metaphorical way with the mystery of Christ (Hos 6:3; 10:12; 13:3). 